\title{
ОЦІНКА ВПЛИВУ НАЯВНОСТІ У ПАЦІЄНТІВ НАДЛИШКОВОÏ МАСИ ТІЛА НА ФІБРОЗ ПЕЧІНКИ
}

\author{
๑Н. М. Гаврилюк, І. Я. Господарський, О. В. Прокопчук, М. Є. Гаврилюк \\ Тернопільський національний медичний університет імені І. Я. Горбачевського МОЗ України
}

РЕзюМЕ. Хронічні дифузні запальні захворювання печінки, надлишкова маса тіла та ожиріння в останні десятиліття залишаються серйозною причиною захворюваності, смертності та інвалідизації населення.

Мета - порівняти вплив надлишкової маси тіла на перебіг фіброзу у пацієнтів зі стеатозом печінки та пацієнтів-реконвалесцентів HCV-інфекції.

Матеріал і методи. У дослідження було включено 115 хворих із фіброзом печінки. До першої групи увійшли хворі, які отримали лікування з приводу HCV-інфекції ( $n=56)$, другу групу склали пацієнти з НАЖXП (n=59). Обстежуваних з кожної групи було поділено на підгрупи залежно від маси тіла відповідно до класифікації IMT, прийнятої ВОО3 (1997 p).

Результати. Наявність надлишкової маси тіла суттєво впливає на клінічний перебіг патологічного процесу фіброзування печінки, що проявилось розвитком цитолітичного синдрому. Відмічалось зростання показників печінкових проб у біохімічному аналізі крові при збільшенні маси тіла. Виявлено прямий помірний взаємозв'язок між ІМТ та АЛТ, АСТ. Показники трансаміназ також корелювали з фіброзом печінки та даними еластографії. Одночасно у цієї категорії хворих діагностували прогностично несприятливі показники порушень ліпідного обміну, а сам фіброз мав тенденцію до прогресування.

Висновки. 1. Встановлено достовірну кореляцію IMT із рівнями АлТ та АСТ у крові ( $r=0,679, p<0,05$ та $\ulcorner=0,674$, p<0,05), що при подальшому збільшенні надлишкової маси тіла може призвести до переходу стеатозу в стеатогепатит.

2. За даними ліпідограми встановлено залежність порушень ліпідного спектра від ІМТ. Особи із надмірною вагою та ожирінням 1 ступеня більше схильні до гіперхолестеринемії, гіпертригліцеридемії $(r=0,318, p<0,05)$ на тлі зменшення ХС ЛПВЩ (r=- 0,219, p<0,05). Ці порушення $\epsilon$ несприятливим фактором перебігу стеатозу, а при поєднанні з фіброзом сприяють його прогресуванню.

3. Надлишкова маса тіла та ожиріння $\epsilon$ підґрунтям для розвитку фіброзних процесів у печінці $(r=0,74, p<0,05)$, а її значне збільшення призводить до виражених фібротичних змін (F2 - F3 за METAVIR).

КлючОВІ СлОВА: фіброз; надлишкова маса тіла; ожиріння.

Вступ. Однією з основних проблем у внутрішній медицині $\epsilon$ неухильне зростання хронічних уражень печінки, як вірусної, так і не вірусної етіології [1-4], що спостерігається в останні десятиліття і $\epsilon$ серйозною проблемою охорони здоров'я в багатьох країнах, оскільки основним контингентом хворих, як правило, є працездатна, соціально активна частина населення [5-10].

На хронічні дифузні захворювання печінки (ХДЗП) у світі страждає більше 2 млрд людей, що перевищує поширеність ВІЛ-інфекції в 100 разів $[11,12]$, а також дію ксенобіотиків і, насамперед, алкоголю та ліків [13-16].

Зловживання алкоголем та іншими токсичними речовинами, поширеність ожиріння, погіршення екологічної ситуації займають друге місце за значимістю в розвитку ХДЗП $[8,17,18]$.

Для опису патологічних змін печінки, що характеризуються запальною інфільтрацією на тлі жирової дистрофії гепатоцитів, на сьогодні вживають термін «стеатогепатит» [19], а The American Gastroenterological Association (AGA) Clinical Practice Committee i The American Association for The Study of Liver Diseases (AASLD) Practice Guidelines Committee рекомендують термін, який об'єднує дві морфологічні форми або стадії хвороби - стеатоз (чи "жирну печінку", англ. "fatty liver") і стеатогепатит як "неалкогольну жирову хворобу печінки" (НАЖХП) [10]. В основі багатьох захворювань печінки, пов'язаних із порушенням метаболічних процесів жирового і вуглеводного обмінів у осіб з алкогольною чи лікарською інтоксикацією у всьому світі предметом пильного вивчення стає і неалкогольна жирова хвороба печінки (НАЖХП), які мають однакову гістологічну картину та подібний патогенез в основі якого $є$ інсулінорезистентність (IP), гіперглікемія з глюкозотоксичністю, ожиріння і метаболічний синдром (MC) $[20,21]$. Фактори токсичних агентів здатні збільшувати вміст вільних жирних кислот у гепатоцитах, знижувати швидкість $\beta$-окисненння їх у мітохондріях, підвищувати продукцію тригліцеридів та холестерину, надмірно поглинати гепатоцитами ВЖК з формуванням стеатозу $[22,23,24]$, що призводить до втрати захисних властивостей гепатоцитів та підвищення їх чутливості до токсичних впливів [25-28]. Вільні радикали сприяють запуску реакцій перекисного окиснення ліпідів (ПОЛ), продукції прозапальних цитокінів, включаючи фактор некрозу пухлин альфа (TNF-a), інтерлейкінів 6 і 8 [29, 30, 31], які при- 
Огляди літератури, оригінальні дослідження, погляд на проблему, випадок з практики, короткі повідомлення

зводять до некрозу гепатоцитів і викликають запальну клітинну інфільтрацію в портальних трактах та печінкових часточках $[32,33]$. Запалення стає додатковим джерелом прооксидантів у печінці, активує каскад реакцій з формуванням стеатогепатиту [34, 35]. Ці патологічні біохімічні процеси, а саме ПОЛ і цитокіновий каскад запалення, порушують функцію клітинного матриксу і зірчастих клітин та рівновагу фіброгенезу і фібролізу в паренхімі печінки з активацією процесу фіброгенезу $[34,36,37]$. Їх стимуляція призводить до продукції компонентів сполучної тканини з розвитком перисинусоїдального або перипортального фіброзу, а з часом - до цирозу печінки (ЦП) і гепатоцелюлярної карциноми (ГЦК) [38, 39].

На ґрунті складних взаємодій між гепатоцитами та клітинами імунної системи і макрофагами, на тлі стеатозу та утворення активних форм кисню відбувається трансформація стеатозу в стеатогепатит і далі в неалкогольний цироз печінки [40]. Незбалансоване харчування з переважанням жирів та вуглеводів призводить до надмірного надходження ліпідів у печінку та ожиріння (ОЖ) за центральним типом, при якому полегшується надходження ВЖК [41]. При недостатності білка та виведенні ліпідів із печінки порушується формування ліпопротеїнів - транспортних форм ліпідів. Унаслідок зменшення їх $\beta$-окиснення в мітохондріях гепатоцитів [17, 42, 43] формуються дистрофічні, запально-некротичні і фібротичні зміни печінки, пов'язані з порушенням процесів ПОЛ і жировим ушкодженням гепатоцитів [44].

Поширеність НАЖХП у популяції становить 20-35 \%, досягаючи до 90 \% в осіб із надлишковою масою тіла та морбідним ожирінням $[45,46]$. Кожна четверта жінка і кожен шостий чоловік в Україні мають надмірну вагу, а близько 30 \% населення страждає від ОЖ [47]. На тлі ОЖ ризик розвитку НАЖХП становить 30-100 \%, а гіпертригліцеридемії - 20-90 \% [48]. У результаті зростання поширеності ОЖ, що має тенденцію до прогресування в усьому світі, збільшується кількість хворих на НАЖХП.

Мета - порівняння впливу надлишкової маси тіла на перебіг фіброзу в пацієнтів зі стеатозом печінки та в пацієнтів-реконвалесцентів HCV-інфекції.

Матеріал і методи дослідження. О6'єКтом дослідження стали пацієнти з фіброзом печінки без супутньої патології з різним індексом маси тіла, які проходили обстеження і отримували лікування у відділенні гастроентерології та гепатології Тернопільської університетської лікарні. Проведено обстеження 115 пацієнтів, яких поділили на дві групи. До першої групи увійшли хворі, які отримували лікування від HCV-інфекції ( $n=56)$, другу групу склали пацієнти з НАЖХП (n=59). О6стежуваних з кожної групи було поділено на підгрупи (рис. 2) залежно від їх маси тіла відповідно до класифікації ІМТ, прийнятої ВООЗ (1997р): 1 підгрупа - пацієнти з нормальною вагою (18,5 -

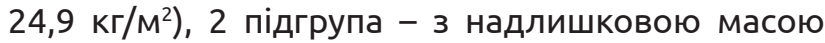

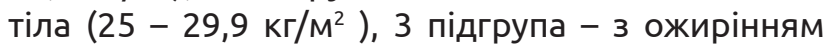
І ступеня (30 - 34,9 кг/м²). 20 здорових осіб склали контрольну групу.

Критерії включення осіб у першу групу: пацієнти, інфіковані вірусом гепатиту С (згідно з даними анамнезу та підтверджено наявністю РНК збудника методом полімеразної ланцюгової реакції), яким проведено противірусне лікування згідно з клінічним протоколом «Вірусний гепатит C» (Наказ МО3 України № 233 від 02.04.2014) та перекладених українською мовою «Настанов 3 лікування та догляду хворих із хронічним вірусним гепатитом С» (розроблених Всесвітньою організацією охорони здоров'я у 2018 р). У всіх пацієнтів цієї групи повторними обстеженнями методом ПлР підтверджено стійку вірусологічну відповідь і зареєстровано видужання від HCV-інфекції.

Критерії включення в другу групу: пацієнти 3 НАЖХП (зокрема з ознаками стеатозу і фіброзу за даними ультразвукового дослідження в поєднанні зі змінами в ліпідограмі або порушенням толерантності до глюкози). Перевищення трансаміназ (АЛТ, АСТ) в обстежуваних більш ніж вдвічі від рівня порогових значень вважалося критерієм НАСГ.

До критеріїв виключення для обох груп належали наявність в анамнезі у пацієнтів вірусних гепатитів, автоімунного, токсичного, медикаментозного й алкогольного гепатитів, метаболічний синдром, недостатня маса тіла та ожиріння IIIII ступенів, наявність супутніх захворювань інших органів та систем. Також у дослідження не включали хворих на неалкогольний стеатогепатит (діагноз, окрім перевищення трансаміназ, також верифікували відповідно до Уніфікованого клінічного протоколу «Неалкогольний стеатогепатит» (Наказ МОЗ України № 826 від 06.11.2014).

Усім хворим було проведено:

- загальноклінічне обстеження (аналіз скарг, анамнезу хвороби, анамнезу життя, об'єктивного статусу);

- антропометричні дослідження, що включали визначення маси тіла, зросту, обводу талії та стегон;

- загальні лабораторні та інструментальні обстеження;

- біохімічні дослідження для визначення функціонального стану печінки, білкового та вуглеводного обміну;

- визначення в сироватці крові загального холестерину, ліпопротеїдів високої щільності 
Огляди літератури, оригінальні дослідження, погляд на проблему, випадок з практики, короткі повідомлення (ЛПвЩ), ліпопротеїдів низької щільності (лПнЩ), ліпопротеїдів дуже низької щільності (ЛпднЩ), тригліцеридів (ТГ);

- сироваткові маркери для визначення індексів FIB-4, NASH та FibroTest ;

- ультразвукове дослідження органів черевної порожнини;

- еластографію печінки (ARFI метод).

ARFI дослідження проводили за допомогою ультразвукової системи Acuson S2000 (Siemens) не менше ніж 10 успішно виконаних вимірювань кожного (IV-VIII) сегмента печінки. Фіброз паренхіми печінки вимірювали за допомогою величини швидкості зсувної хвилі (м/с) і класифікували за допомогою шкали METAVIR залежно від швидкості зсувної хвилі. Для кожного пацієнта було визначено співвідношення АСТ/АЛТ (AAR), індекси NFS [50] та FIB-4 [51]. Індекси вираховували за формулами:

FIB-4=(вік (роки) × АСТ (од. л))/ (тромбоцити $\left.\left(\times 10^{9} / \text { л) } \times \text { АЛТ (од./л) }\right)^{1 / 2}\right)$.

$\mathrm{NFS}=-1,675+0,037 \times$ вік (роки) $+0,094 \times \mathrm{IMT}\left(\mathrm{\kappa г} / \mathrm{M}^{2}\right)$ $+1,13 \times$ порушена толерантність до глюкози або ЦД (так=1, ні=0) + 0,99 × АСТ/АЛТ - 0,013 × тром-

боцити $\left(\times 10^{9} / л\right)-0,66 \times$ альбумін (г/дл).

Отримані дані опрацьовано за допомогою комп'ютерних програм Microsoft Office Excel 2007 (Microsoft Corp., США), SPSS for Windows 10.0

(SPSS Inc., США) i Statistica 10.0 (StatSoftInc., США). При статистичному аналізі використовували описовий метод статистики, враховуючи закони розподілу і критерії Колмогорова-Смірнова та Шапіро-Уілка (при значенні p>0,05 та p>0,2 розподіл вважали нормальним). Дані кількісних ознак подані у вигляді кількості спостережень (n), середньої величини (М) та стандартної похибки середньої величини (m); якісні дані - у вигляді відносних показників (\%). Кореляційний аналіз між окремими показниками отримали за допомогою коефіцієнта кореляції Спірмена для непараметричних даних.

Результати й обговорення. Віковий склад обстежених хворих коливався від 22 до 74 років. Переважали пацієнти працездатного віку 45-59 років $(45,22 \%)$. Середній вік хворих склав $(49,68 \pm 1,03)$ років. Чоловіків було 57 (49,6\%), жінок - 58 (50,4 \%). Серед обстежених I групи було 29 (25,22 \%) чоловіків та $27(23,48 \%)$ жінок (середній вік $(45,62 \pm 2,00)$ та $(53,41 \pm 1,91)$ років). У II групі частка чоловіків та жінок відповідно становила 28 (24,35 \%) і 31 (26,95\%), середній вік $(48,71 \pm 2,37)$ та $(51,1 \pm 1,78)$ років. Установлено прямий помірний зв'язок між вагою та статтю ( $r=0,30, p<0,05)$, який підтверджує схильність до надмірної ваги у жінок. Статева та вікова структура обстежуваних хворих представлена на рисунку 1.

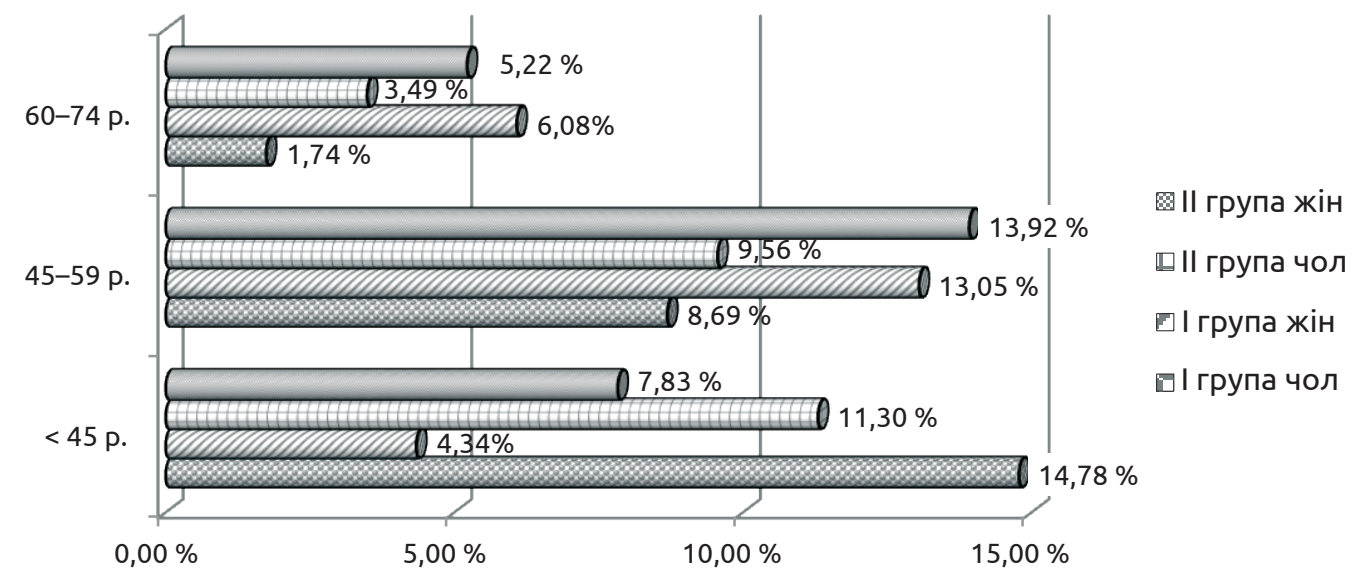

Рис. 1. Статева та вікова структура обстежуваних хворих.

Таблиця 1. Розподіл хворих залежно від маси тіла відповідно до класифікації ІМТ

\begin{tabular}{|c|c|c|c|c|c|}
\hline \multicolumn{3}{|c|}{ І група } & \multicolumn{3}{c|}{ II група } \\
\hline IMT 1.1 & IMT 1.2 & IMT 1.3 & IMT 2.1 & IMT 2.2 & IMT 2.3 \\
$18,5-24,9 \mathrm{Kr} / \mathrm{M}^{2}$ & $25-29,9 \mathrm{Kr} / \mathrm{M}^{2}$ & $30-34,9 \mathrm{Kr} / \mathrm{M}^{2}$ & $18,5-24,9 \mathrm{Kr} / \mathrm{M}^{2}$ & $25-29,9 \mathrm{Kr} / \mathrm{M}^{2}$ & $30-34,9 \mathrm{Kr} / \mathrm{M}^{2}$ \\
\hline $17(14,78 \%)$ & $18(15,65 \%)$ & $21(18,26 \%)$ & $18(15,65 \%)$ & $18(15,65 \%)$ & $23(20 \%)$ \\
\hline
\end{tabular}

Для визначення підвищеного ризику абдомінального ожиріння вимірювали обвід талії (ОТ) і обвід стегон (ОС). Розраховували співвідношення
ОТ / ОС. у 34 обстежених чоловіків (29,56 \%) та у 16 жінок (13,91\%) цей показник був більшим за 0,9 i, за даними літератури, свідчив про збільшен- 
Огляди літератури, оригінальні дослідження, погляд на проблему, випадок з практики, короткі повідомлення ня кількості абдомінального жиру [47, 52]. Найбільшою окружність була у підгрупах 1.3 і 2.3, в яких пацієнти мали ІМТ 30-34,9 кг/м². Виявлено прямий помірний зв'язок між статтю та співвідношенням цих об'ємів, який вказує на те, що чоловіки більш схильні до даного типу ожиріння ( $r=0,33$; p<0,05). Також спостерігається пряма слабка залежність від зросту пацієнтів $(r=0,23 ; p<0,05)$ та помірна - від маси тіла і, відповідно, ІМТ ( $r=0,55$; p<0,05 та $\ulcorner=0,53 ; p<0,05)$. Дані, наведені нижче, демонструють цю залежність (табл. 2). Показник зросту в усіх обстежуваних вірогідно не відрізнявся.

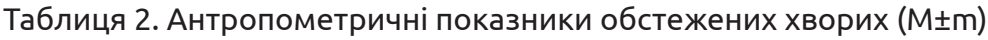

\begin{tabular}{|l|c|c|c|c|c|c|}
\hline \multirow{2}{*}{ Показник } & \multicolumn{5}{|c|}{ Підгрупи } \\
\cline { 2 - 7 } & 1.1 & 1.2 & 1.3 & 2.1 & 2.2 & 2.3 \\
\hline ОТ & $79,82 \pm 2,20$ & $87,28 \pm 1,91$ & $103,38 \pm 1,72^{*}$ & $81,11 \pm 2,61$ & $88,06 \pm 1,36$ & $110 \pm 1,73^{*}$ \\
\hline ОС & $98,18 \pm 1,26$ & $104,89 \pm 1,74$ & $114,43 \pm 1,76$ & $96,06 \pm 1,63$ & $102,11 \pm 1,60$ & $112,96 \pm 1,64$ \\
\hline ОТ/ОС & $0,81 \pm 0,02$ & $0,84 \pm 0,01$ & $0,94 \pm 0,04^{*}$ & $0,85 \pm 0,02$ & $0,87 \pm 0,01$ & $0,98 \pm 0,02^{*}$ \\
\hline Маса тіла & $64,47 \pm 1,95$ & $76,67 \pm 2,18$ & $94,14 \pm 2,64^{*}$ & $63,89 \pm 2,07$ & $75,28 \pm 1,74$ & $95,74 \pm 2,27^{*}$ \\
\hline Зріст & $169,76 \pm 1,80$ & $168,61 \pm 1,91$ & $168,48 \pm 1,63$ & $167,33 \pm 2,34$ & $166,72 \pm 1,87$ & $171,09 \pm 1,89$ \\
\hline ІМТ & $22,31 \pm 0,41$ & $26,98 \pm 0,39$ & $33,21 \pm 0,35^{*}$ & $22,78 \pm 0,37$ & $27,07 \pm 0,41$ & $32,63 \pm 0,33^{*}$ \\
\hline
\end{tabular}

Примітка. * - різниця щодо показників статистично значуща $(p<0,05)$.

Після аналізу функціонального стану печінки отримано дані, які свідчать, що рівень трансаміназ не підвищувався більше 2 норм у жодній з груп. Середні значення АЛТ та АСТ у всіх підгрупах незначно відрізнялись, проте більшими були в тих, до яких увійшли пацієнти-реконвалесценти HCVінфекції. Відмічалось зростання показників печінкових проб у біохімічному аналізі крові при збіль- шенні маси тіла. Виявлено прямий помірний взаємозв'язок між ІМТ та АЛТ, АСТ (відповідно $r=0,679, p<0,05 ; r=0,674, p<0,05)$. Показник трансаміназ також корелював із фіброзом печінки та даними еластографії ( $r=0,61, p<0,05 ; r=0,67, p<0,05)$. У всіх пацієнтів були відсутні холестаз, мезенхімальне запалення та порушення білковосинтезувальної функції печінки (табл. 3).

Таблиця 3. Клініко-лабораторна характеристика пацієнтів

\begin{tabular}{|l|c|c|c|c|c|c|}
\hline \multirow{2}{*}{ Показник } & \multicolumn{5}{|c|}{ Підгрупи } \\
\cline { 2 - 6 } & 1.1 & 1.2 & 1.3 & 2.1 & 2.2 & 2.3 \\
\hline $\begin{array}{l}\text { Загальний } \\
\text { білірубін }\end{array}$ & $12,82 \pm 1,09$ & $14,63 \pm 1,44$ & $11,31 \pm 0,95$ & $11,81 \pm 0,67$ & $11,41 \pm 1,21$ & $13,29 \pm 1,61$ \\
\hline $\begin{array}{l}\text { Прямий } \\
\text { білірубін }\end{array}$ & $4,46 \pm 0,77$ & $4,46 \pm 0,53$ & $3,68 \pm 0,36$ & $3,85 \pm 0,29$ & $3,47 \pm 0,49$ & $4,76 \pm 0,60$ \\
\hline Алт & $26,59 \pm 2,1$ & $35,91 \pm 2,25$ & $49,34 \pm 2,88^{*}$ & $21,11 \pm 2,33$ & $37,14 \pm 3,56$ & $47,61 \pm 2,75$ \\
\hline АСТ & $32,87 \pm 2,85$ & $42,69 \pm 2,92^{*}$ & $54,95 \pm 3,55^{*}$ & $19,92 \pm 1,84$ & $41,27 \pm 3,47^{*}$ & $57,76 \pm 3,41^{*}$ \\
\hline $\begin{array}{l}\text { Коефіцієнт де } \\
\text { Рітіса }\end{array}$ & $1,21 \pm 0,05$ & $1,19 \pm 0,03$ & $1,12 \pm 0,05$ & $0,98 \pm 0,05$ & $1,15 \pm 0,05$ & $1,22 \pm 0,03$ \\
\hline ГГГТ & $27,77 \pm 5,68$ & $26,59 \pm 2,05$ & $35,86 \pm 5,02$ & $27,58 \pm 2,25$ & $32,65 \pm 4,24$ & $44,17 \pm 7,37$ \\
\hline $\begin{array}{l}\text { Лужна } \\
\text { фосфатаза }\end{array}$ & $60,76 \pm 5,38$ & $63,39 \pm 4,83$ & $77,86 \pm 4,47$ & $58,28 \pm 4,86$ & $62 \pm 4,79$ & $73,48 \pm 5,71$ \\
\hline Білок & $67,60 \pm 1,71$ & $68,59 \pm 0,97$ & $72,37 \pm 1,02$ & $66,19 \pm 4,35$ & $67,38 \pm 3,62$ & $71,29 \pm 1,95$ \\
\hline Альбумін & $43,82 \pm 1,26$ & $43,11 \pm 1,02$ & $40,90 \pm 1,05$ & $38,56 \pm 1,10$ & $40,33 \pm 0,86$ & $35,61 \pm 0,85$ \\
\hline Тимолова проба & $3,21 \pm 0,29$ & $3,46 \pm 0,28$ & $3,65 \pm 0,29$ & $4,27 \pm 0,20$ & $2,94 \pm 0,23$ & $3,22 \pm 0,27$ \\
\hline Еластографія & $1,27 \pm 0,01$ & $1,38 \pm 0,01^{*}$ & $1,49 \pm 0,04^{*}$ & $1,09 \pm 0,02$ & $1,29 \pm 0,01$ & $1,43 \pm 0,2^{*}$ \\
\hline
\end{tabular}

Примітка. * - різниця щодо показника пацієнтів при збільшенні маси тіла статистично значуща $(p<0,05)$.

При вивченні ліпідного спектра (рис. 2) у пацієнтів з IMT 30-34,9 кг/м² виявлено, що загальний холестерин був збільшений в 1,07 раза відносно

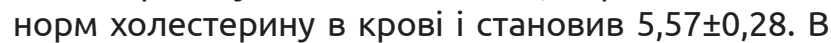
усіх інших групах цей показник був у межах норми. Рівень ЛПВЩ у всіх групах був знижений в середньому в 1,2-1,3 раза, а в підгрупі 2.3 - в 1,5 раза. Отримали незначне підвищення ЛПНЩ у всіх об- стежуваних пацієнтів в середньому в 1,2 раза. Встановлено прямий помірний взаємозв'язок між IMT та рівнями ліпопротеїдів дуже низької щільності і тригліцеридів (відповідно $r=0,324, p<0,05$ i $r=0,318, p<0,05)$, прямий слабкий - з коефіцієнтом атерогенності $(r=0,227, p<0,05)$, а також зворотний слабкий - з рівнем ліпопротеїдів високої щільності $(r=-0,219, p<0,05)$. 
Огляди літератури, оригінальні дослідження, погляд на проблему, випадок з практики, короткі повідомлення

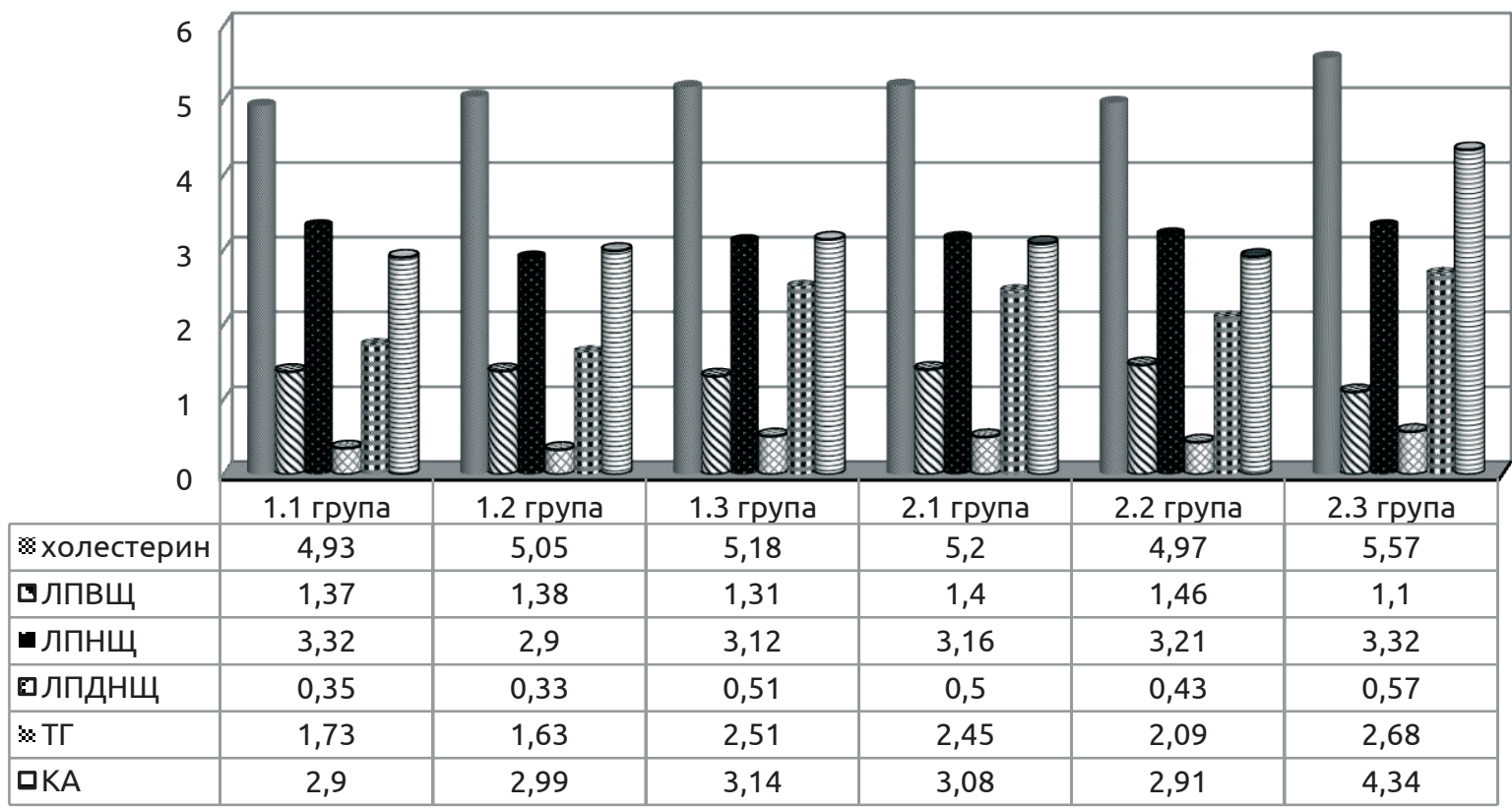

Рис. 2. Динаміка основних показників ліпідного обміну.

У результаті аналізу даних еластографії встановлено, що у $18(15,65 \%)$ пацієнтів фіброзу печінки не було (F0), проте під час Уз обстеження виявили ознаки стеатозу. До них належать гепаторенальний індекс - збільшення ехогеності печінки порівняно з ниркою, та додатково один із параметрів: знижена звукопровідність, утруднена візуалізація діафрагми, розмиття судин, ділянки незміненої паренхіми, погана візуалізація стінки жовчного міхура (критерії Ballestri et al. (2012)). При аналізі лабораторних даних у частини обсте- жуваних виявлені зміни в ліпідограмі, а в інших порушення толерантності до глюкози. У кількох обстежених відмітили нестабільне підвищення АТ у межах високого нормального АТ. Метаболічного синдрому у даних пацієнтів не виявлено. Всі ці пацієнти увійшли до підгрупи 1.1. Початковий фіброз (F1) виявили у 52 (45,22 \%) хворих, які увійшли у всі інші підгрупи залежно від IMT. У 37 $(32,17 \%)$ осіб верифікували помірний фіброз (F2), 8 (6,96 \%) пацієнтів мали виражений фіброз (F3) (рис. 3).

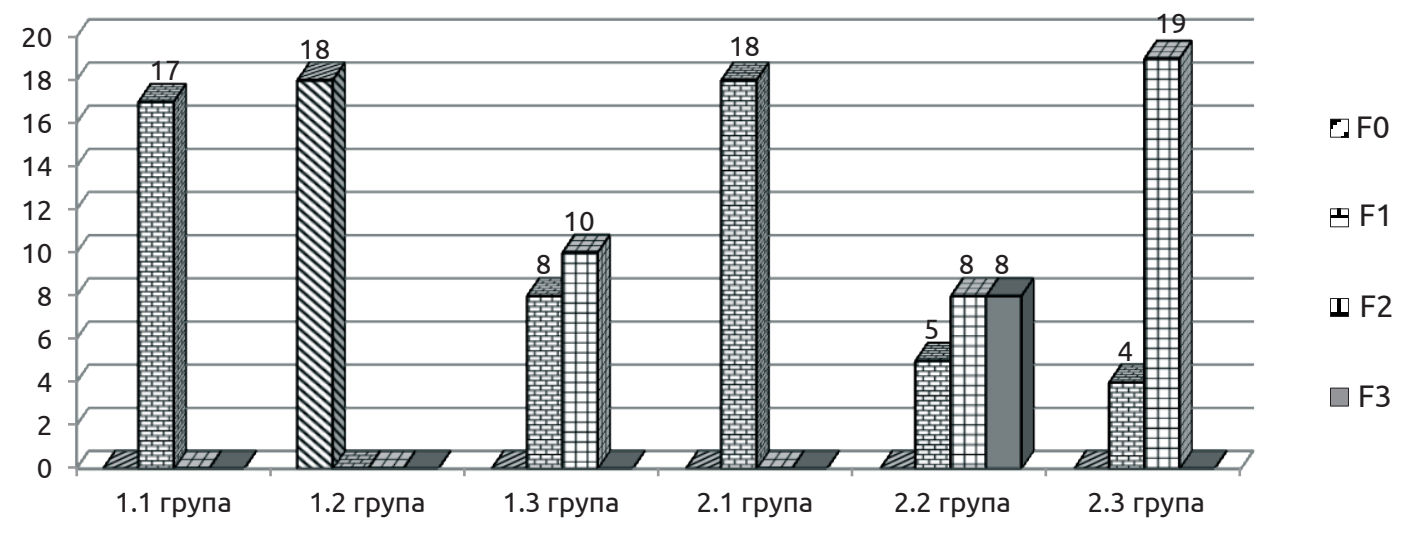

Рис. 3. Розподіл пацієнтів за ступенем фіброзу.

Отримано прямий сильний взаємозв'язок між IMT та середнім значенням даних еластографії печінки $(r=0,74, p<0,05)$, неінвазивним тестом FIB4 $(r=0,88, p<0,05)$ та NFS $(r=0,89, p<0,05)$.

Висновки. 1. Встановлено достовірну кореляцію ІМТ з рівнями АЛТ та АСТ у крові $(r=0,679$, $p<0,05$ та $r=0,674, p<0,05)$, що, при подальшому збільшенні надлишкової маси тіла, може призвести до переходу стеатозу в стеатогепатит.

2. За даними ліпідограми встановлено залежність порушень ліпідного спектра від IMT. Особи з надмірною вагою та ожирінням 1 ступеня більше 
Огляди літератури, оригінальні дослідження, погляд на проблему, випадок з практики, короткі повідомлення схильні до гіперхолестеринемії, гіпертригліцеридемії $(r=0,318, p<0,05)$ на тлі зменшення ХС лПВЩ ( $г=-0,219, p<0,05)$. Ці порушення $\epsilon$ несприятливим фактором перебігу стеатозу, а при поєднанні з фіброзом сприяють його прогресуванню.

3. Надлишкова маса тіла та ожиріння $\epsilon$ підґрунтям для розвитку фіброзних процесів у печінці $(r=0,74, p<0,05)$, а її значне збільшення призводить до виражених фібротичних змін (F2 - F3 за METAVIR) .

\section{ЛІТЕРАТУРА}

1. Вовк Е. И. Неалкогольная жировая болезнь печени: от научных достижений к клиническим алгоритмам / Е. И. Вовк // Медицинский совет. - 2013. - № 10. C. 46-53.

2. Morbid obesity in pediatric diabetes mellitus: surgicaloptionsandout-comes / M. L. Brandt, C. M. Harmon, M. A. Helmrath [et al.] // Nature Reviews Endocrinology. 2010. - Vol. 6. - P. 637-664

3. Management of chronic liver disease by general practitioners in southern Italy: unmet educational needs / C. Loguercio, A. Tiso, G. Cotticelli [et al.] // Digestive and Liver Disease. - 2011. - Vol. 43. - P. 736-741.

4. Byrne C. D. Ectopic fat, insulin resistance, and nonalcoholic fatty liver disease: implications for cardiovascular disease / C. D Byrne, G. Targher // Arteriosclerosis, Thrombosis, and Vascular Biology. - 2014. - Vol. 34 (6). P. 1155-1161.

5. Arun J. S. AGA technical review on nonalcoholic fatty liver disease / J. S. Arun // Gastroenterology. - 2002. Vol. 123. - P.1705-1725.

6. Byrne C. D. NAFLD: a multisystem disease / C. D. Byrne, G. Targher // Journal of Hepatology. - 2015. Vol. 62 (1), Suppl. - P. 47-64.

7. Неалкогольная жировая болезнь печени: терапевтические возможности L-карнитина / H. В. Харченко, И. Н. Скрыпник, В. В. Харченко [та ін.] // Здоров'я України. - 2017. - № 1 (43). - С. 28-30.

8. Степанов Ю. М. Стеатоз печени и стеатогепатит - неизбежность смешанного генеза / Ю. М. Степанов // Гастроентерологія. - 2014. - № 4 (54). C. $136-142$.

9. Звягинцева Т. Д. Неалкогольный стеатогепатит: механизмы развития и тактика лечения / Т. Д. Звягинцева, С. В. Глущенко // Здоров'я України. - 2017. № (43). - С. 40-41.

10. Диагностика и лечение больных с неалкогольной жировой болезнью печени: практические рекомендации Американской ассоциации по изучению заболеваний печени, Американского колледжа гастроэнтерологии и Американской гастроэнтерологической ассоциации // Сучасна гастроентерологія. - 2014. № 3 (77). - C. 89-104.

11. Emerging drugs for non-alcoholic steatohepatitis / W. Tomeno, M. Yoneda, K. Imajo [et al.] // Expert Opinion Emerging Drugs. - 2013. - Vol. 18 (3). - P. 279-290.

12. Гастроентерологія : підручник: у 2 т / За ред. Харченко Н. В., Бабака О. Я. - 2-е вид., переробл., доповн. - Кіровоград : Поліум, 2016. - Т. 1. - 488 с.

13. Соломенцева Т. А. Неалкогольная жировая болезнь печени и метаболические нарушения: что первично? / Т. А. Соломенцева // Сучасна гастроентерологія. - 2017. - № 6 (98). - С. 51-57.

14. Алкогольная болезнь печени и алкоголизм две болезни и одна проблема / А. А. Самсонов, Е. Ю. Плотникова, И. Н. Никушкина [и др.] // Медицинский совет. 2013. - № 10. - С. 38-41.

15. Проблемы диагностики неалкогольной жировой болезни печени / О. В. Тирикова, Н.М.Козлова, С. М. Елисеев, Р. Р. Гумеров // Сибирский медицинский журнал. - 2015. - № 7. - С. 33-39.

16. Scaglioni F. ASH and NASH / F. Scaglioni // Digestive Diseases. - 2011. - Vol. 29 (2). - P. 202-210.

17. Комшилова К. А. Ожирение и неалкогольная жировая болезнь печени: метаболические риски и их коррекция / К. А. Комшилова, Е. А. Трошина // Ожирение и метаболизм. - 2015. - № 12 (2). - С. 35-39.

18. Стародубова А. В. Избыточная масса тела и ожирение как факторы риска неалкогольной жировой болезни печени / А. В. Стародубова // Архив внутренней медицины. - 2014. - № 5 (19). - С. 10-20.

19. Day C. P. Steatohepatitis: a tale of two "hits"? / C. P. Day, O. F. James // Gastroenterology. - 1998. Vol. 114. - P. 842-845.

20. Ройтберг Г. Е. Роль метаболического синдрома и его компонентов в патогенезе и прогрессировании неалкогольного стеатогепатита / Г. Е. Ройтберг, О. О. Шархун, Н. В. Кондратова, Т. И. Ушакова // Гепатология. 2005. - № 5. - С. 30-36.

21. Коковина Ю. В. Применение комбинированных гепатопротекторов у пациентов с диффузными изменениями печени и с измененным липидным спектром / Ю. В. Коковина, О. Н. Вишневская // Русский медицинский журнал. - 2015. - № 2. - С. 86-88.

22. Оковитый С. В. Митохондриальная дисфункция при метаболическом синдроме / С. В. Оковитый // Эффективная фармакотерапия. - 2015. -№16. - C. 46-48.

23. Angulo P. Independent predictor sofliver fibrosis in patients with non-alcoholicsteatohepatitis / P. Angulo, J. C. Keach, K. P. Battsetal // Hepatology. - 1999. Vol. 30 (6). - P. 1356-1362.

24. Філіппова О. Ю. Морфологічні параметри неалкогольного та алкогольного стеатогепатитів у хворих із патологією біліарного тракту / О. Ю. Філіппова // Світ медицини та біології. - 2011. - № 1. - С. 107-110.

25. Bettowski J. Leptin and the regulation of endothelial function in physiological and pathological conditions / J. Bettowski // Clinical and Experimental Pharmacology Physiology. - 2012. - Vol. 39 (2). - P.168-178.

26. Чернова В. М. Многофакторность патогенеза неалкогольной жировой болезни печени / В. М. Чернова // Сучасна гастроентерологія. - 2017. - № 6 (98). C. 92-101.

27. Содержание провоспалительных цитокинов в зависимости от стадии фиброза у больных с метаболи- 
Огляди літератури, оригінальні дослідження, поглядн на ческим синдромом и неалкогольной жировой болезнью печени / Л. В. Чеснокова, И. М. Петров, И. А. Трошина, И. В. Медведева // Клиническая медецина. - 2013. № 12 (91). - С. 34-38.

28. Increased hepatic and circulating interleukin-6 levels in human non-alcoholic steatohepatitis / A. Wieckowska, B. G. Papouchado, Z. Li [et al.] // Am. J. Gastroenterol. - 2008. - Vol. 103. - P. 1372-1379.

29. Буеверов А. О. «Цитокиновый взрыв» и прогрессирование неалкогольного стеатогепатита / А. О. Буеверов, П. О. Богомолов // Клин. перспективы гастроэнтерол. гепатол. - 2012. - № 5. - С. 12-18.

30. Serum cytokine and soluble cytokine receptor levels in patients with non-alcoholic steatohepatitis / S. Abiru, K. Migita, Y. Maeda [et al.] // Liver Internatial. - 2006. Vol. 26. - P. 39-45.

31. IL28B and PNPLA3 polymorphisms affect histological liver damage in patients with non-alcoholic fatty liver disease / S. Petta, S. Grimaudo, C. Camma [et al.] // Journal of Hepatology. - 2012. - Vol. 56 (6). - P. 1356-1362.

32. Diagnostic accuracy and reliability of ultrasonography for the detection of fatty liver: ameta-analysis / R. Hernaez, M. Lazo, S. Bonekamp [et al.] // Hepatology. 2011. - Vol. 54 (3). - P. 1082-1090.

33. Suh Y. G. Hepatic stellate cells and innate immunity in alcoholic liver disease / Y. G. Suh, W. I. Jeong // World Journal of Gastroenterology. - 2011. - Vol. 17 (20). P. 2543-2551.

34. Маммаев С. Н. Цитокиновая система при неалкогольном стеатогепатите / С. Н. Маммаев, Н. В. Багомедова, П. О. Богомолов // Рос. журн. гастроэнтерол. гепатол. колопроктол. - 2007. - № 4. - С. 35-39.

35. A novel marker fo rassessment of liver matrix remodeling: anenzyme-linked immune sorbent assay (ELISA) detecting a MMP generated type I collagen neo-epitope (C1M) / D. Leeming, Y. He, S. Veidal [et al.] // Biomarkers. 2011. - Vol. 16, No. 7. - P. 616-628.

36. Спосіб діагностики стадії фіброзу печінки: патент 123951 Україна: МПК А61В 8/00 (2018.01) / Господарський І. Я., Гаврилюк Н. М., Господарська Х. О., Прокопчук О. В. - № ч 2017 10483; заявл. 30. 10. 2017; опубл. 12.03.2018, Бюл. № 5. - 4 с.

37. Assessment of endothelial function in patients with non-alcoholic fatty liver disease / Y. Colak, E. Senates, A. Yesil [et al.] // Endocrine. - 2013. - Vol. 43. - P. 100-107.

38. Бобров А. Н. Цирроз печени: этиологические, эпидемиологические, клинико-диагностические и профилактические аспекты по данным 15-летнего (19962010 гг.) наблюдения в многопрофильном госпитале: автореф. дис. на соискание ученой степени докт. мед. наук / А. Н. Бобров. - Москва, 2011. -51 с.

39. Frequency and outcomes of liver transplantation for nonalcoholic steatohepatitis in the United States / M. R. Charlton, J. M. Burns, R. A. Pedersen [et al.] // Gastroenterology. - 2011. - Vol. 141. - P.1249-1253.

40. Oxidative stress as a critical factor in nonalcoholic fatty liver disease pathogenesis / S. Spahis, E. Delvin, J. M. Borys, E. Levy // Antioxid Redox Signal. - 2017. Vol. 26 (10). - P. 519-541.

41. Адипонектин и показатели метаболизма глюкозы и липидов на разных клинико-морфологических стадиях неалкогольной жировой болезни печени у больных абдоминальным ожирением / К. А. Комшилова, Е. А. Трошина, Е. В. Ершова [и др.] // Терапевт. архив. - 2014. - № 10. - С. 27-32.

42. Балукова Е. В. Неалкогольная жировая болезнь печени и метаболический синдром / Е. В. Балукова, Ю. П. Успенский // Гастроэнтерология. - 2014. -Спец. вып. № 1. - С. 45-48.

43. Вялов С. С. Жировая болезнь печени: особенности патогенеза, диагностика и терапевтический потенциал / С. С. Вялов // Consilium Medicum. - Гастроэнтерология. - 2014. - № 8. - С. 72-77.

44. Manne V. Pathophysiology of nonalcoholic fatty liver disease/nonalcoholic steatohepatitis / V. Manne, P. Handa, K. V. Kowdley // Clinical Liver Disease - 2018. Vol. 22 (1). - P. 23-37.

45. Мельниченко Г. А. Распространённость неалкогольной жировой болезни печени при ожирении и ее взаимосвязь с факторами риска сердечно-сосудистых заболеваний и сахарного диабета 2-го типа / Г. А. Мельниченко, А. Ю. Елисеева, М.В.Маевская // Российский журнал гастроэнтерологии, гепатологии, колопроктологии. - 2012. - № 5. - С. 45-52.

46. Association of non-alcoholic fatty liver disease with components of metabolic syndrome according to body mass index in Korean adults / Y. M. Kwon, S. W. Oh, S. S. Hwang [et al.] // Am. J. Gastroenterology. - 2012. Vol. 107. - P. 1852-1858.

47. Фадєєнко Г. Д. Особливості харчової поведінки хворих на неалкогольний стеатогепатит з надлишковою масою тіла або ожирінням на тлі артеріальної гіпертензії / Г. Д. Фадєєнко, Я. В. Нікіфорова // Сучасна гастроентерологія. - 2016. - № 2. - С. 7-14.

48. VLDL triglyceride kinetics in lean, overweight, and obese men and women / B. Mittendorfer, M. Yoshino, B. W. Patterson, S. Klein // Journal of Clinical Endocrinology \& Metabolism. - 2016. - Vol. 101. - P. 4151-4160.

49. Dalleck L. C. A community-based exercise intervention transitions metabolically abnormal obese adults to a metabolically healthy obese phenotype / L. C. Dalleck, G. P. Van Guider, T. B. Richardson // Diabetes, Metabolic Syndrome and Obesity. - 2014. - No. 7. - P. 369-380.

50. Angulo P. NAFLD fibrosis score A noninvasive system that identifies liver fibrosis in patients with NAFLD / P. Angulo, J. M. Hui, G. Marchesini // Hepatology. - 2007. Vol. 45 (4). - P. 846-854.

51. Machado M. V. Non-invasive diagnosis of non-alcoholic fatty liver disease. A critical appraisal / M. V. Machado, H. Cortez-Pinto // Journal of Hepatology. - 2013. Vol. 58. - P. 1007-1019.

52. Obesity World Gastroenterology Organisation Global Guideline / J. Toouli, M. Fried, A. G. Khan [et al.] // WGO Global Guideline. Obesity. - 2009. - 30 p. 


\section{Огляди літератури, оригінальні дослідження, погляд на проблему, випадок з практики, короткі повідомлення REFERENCES}

1. Vovk, E.I. (2013). Nealkogolnaya zhirovaya bolezn pecheni: ot nauchnykh dostizheniy k klinicheskim algoritmam [Non-alcoholic fatty liver disease: from scientific advanc es to clinical algorithms]. Meditsinskiy sovet - Medical Counsel, 10, 46-53 [in Russian].

2. Brandt, M.L., Harmon, C.M., \& Helmrath, M.A. (2010). Morbid obesity in pediatric diabetes mellitus: surgicaloptionsandout-comes. Nature Reviews Endocrinology, 6, 637-664

3. Loguercio, C., Tiso, A., \& Cotticelli, G. (2011). Management of chronic liver disease by general practitioners in southern Italy: unmet educational needs. Digestive and Liver Disease, 43, 736-741.

4. Byrne, C.D., \& Targher, G. (2014). Ectopic fat, insulin resistance, and nonalcoholic fatty liver disease: implications for cardiovascular disease. Arteriosclerosis, Thrombosis, and Vascular Biology, 34 (6), 1155-1161.

5. Arun J. S. (2002). AGA Technical review on nonalcoholic fatty liver disease. Gastroenterology, 123, 17051725.

6. Byrne, C.D., \& Targher, G. (2015). NAFLD: a multisystem disease. Journal of Hepatology, 62 (1), Suppl, 47-64.

7. Kharchenko, N.V., Skrypnik, I.N., \& Kharchenko, V.V. (2017). Nealkogolnaya zhirovaya bolezn pecheni: terapevticheskiye vozmozhnosti L-karnitina [Non-alcoholic fatty liver disease: therapeutic potential of L-carnitine]. Zdorovia Ukrainy - Health of Ukraine, 1 (43), 28-30 [in Russian].

8. Stepanov, Yu.M. (2014). Steatoz pecheni i steatogepatit - neizbezhnost smeshannogo geneza [Liver steatosis and steatohepatitis - inevitability of mixed genesis]. Gastroyenterologiya - Gastroenterology, 4 (54), 136-142 [in Russian].

9. Zvyagintseva, T.D., \& Glushchenko, S.V. (2017). Nealkogolnyy steatogepatit: mekhanizmy razvitiya i taktika lecheniya [Non-alcoholic steatohepatitis: mechanisms of development and treatment tactics]. Zdorovia Ukrainy Health of Ukraine, 1 (43), 4041 [in Russian].

10. Diagnostika i lecheniye bolnykh s nealkogolnoy zhirovoy boleznyu pecheni: prakticheskiye rekomendatsii Amerikanskoy assotsiatsii po izucheniyu zabolevaniy pecheni, Amerikanskogo kolledzha gastroenterologii i Amerikanskoy gastroenterologicheskoy assotsiatsii (2014) [Diagnosis and treatment of patients with non-alcoholic fatty liver disease: A practical guideline from the American Association for the Study of Liver Diseases, the American College of Gastroenterology, and the American Gastroenterological Association]. Suchasna gastroyenterologiya Modern Gastroenterology, 3 (77), 89-104 [in Russian].

11. Tomeno, W., Yoneda, M., \& Imajo, K. (2013). Emerging drugs for non-alcoholic steatohepatitis. Expert Opinion Emerging Drugs, 18 (3), 279-290.

12. Xarchenko, N.V., \& Babak, O.Ya. (2016). Gastroenterologiya: pidruchnyk: u 2 tomakh [Gastroenterology: textbook: in 2 volumes]. Kirovograd: Polium [in Ukrainian].

13. Solomentseva, T.A. (2017). Nealkogolnaya zhirovaya bolezn pecheni i metabolicheskiye narusheniya: chto pervichno? [Non-alcoholic fatty liver disease and metabolic disorders: what comes first?] Suchasna gastroyenterologiyaModern Gastroenterology, 6 (98), 51-57 [in Russian].

14. Samsonov, A.A., Plotnikova, E.Yu., \& Nikushkina, I.N. (2013). Alkogolnaya bolezn pecheni i alkogolizm - dve bolezni i odna problema [Alcoholic liver disease and alcoholism are two diseases and one problem]. Meditsinskiy sovet - Medical Counsel, 10, 38-41 [in Russian].

15. Tirikova, O.V., Kozlova, N.M., Eliseyev, S.M., \& Gumerov, R.R. (2015). Problemy diagnostiki nealkogolnoy zhirovoy bolezni pecheni [Problems in the diagnosis of non-alcoholic fatty liver disease]. Sibirskiy meditsinskiy zhurnal - Siberian Medical Journal, 7, 33-39 [in Russian].

16. Scaglioni, F. (2011). ASH and NASH. Digestive Diseases, 29 (2), 202-210.

17. Komshilova, K.A., \& Troshina, K.A. (2015). Ozhireniye i nealkogolnaya zhirovaya bolezn pecheni: metabolicheskiye riski i ikh korrektsiya [Obesity and non-alcoholic fatty liver disease: metabolic risks and their correction]. Ozhireniye i metabolizm - Obesity and Metabolism, 12 (2), 35-39 [in Russian].

18. Starodubova, A.V. (2014). Izbytochnaya massa tela i ozhireniye kak faktory riska nealkogolnoy zhirovoy bolezni pecheni [Overweight and obesity as risk factors for non-alcoholic fatty liver disease]. Arkhiv vnutrenney meditsiny - Achieve of Internal Medicine, 5 (19), 10-20 [in Russian].

19. Day C.P., James O.F. (1998). Steatohepatitis: a tale of two "hits"? Gastroenterology, 114, 842-845.

20. Roytberg, G.E., Sharkhun, O.O., Kondratova, N.V., \& Ushakova, T.I. (2015). Rol metabolicheskogo sindroma i ego komponentov v patogeneze i progressirovanii nealkogolnogo steatogepatita [The role of metabolic syndrome and its components in the pathogenesis and progression of non-alcoholic steatohepatitis]. Gepatologiya - Hepatology, 5, 30-36 [in Russian].

21. Kokovina, Yu.V., \& Vishnevskaya, O.N. (2015). Primeneniye kombinirovannykh gepatoprotektorov u patsiyentov s diffuznymi izmeneniyami pecheni i s izmenennym lipidnym spektrom [The use of combined hepatoprotectors in patients with diffuse liver changes and altered lipid spectrum]. Russkiy meditsinskiy zhurnal - Russian Medical Journal, 2, 86-88 [in Russian].

22. Okovityy, S.V. (2015). Mitokhondrialnaya disfunktsiya pri metabolicheskom sindrome [Mitochondrial dysfunction in metabolic syndrome]. Effektivnaya farmakoterapiya - Effective Pharmacotherapy, 16, 46-48 [in Russian].

23. Angulo, P., Keach, J.C., \& Battsetal, K.P. (1999). Independent predictor sofliver fibrosis in patients with non-alcoholicsteatohepatitis. Hepatology, 30 (6), 13561362.

24. Filippova, O.Yu. (2011). Morfolohichni parametry nealkoholnoho ta alkoholnoho steatohepatytiv u khvorykh iz patolohiieiu biliarnoho traktu [Morphological parameters of non-alcoholic and alcoholic steatohepatitis in patients with biliary tract pathology]. Svit medytsyny ta biolohii - World of Medicine and Biology, 1, 107-110 [in Ukrainian].

25. Bettowski, J. (2012). Leptin and the regulation of endothelial function in physiological and pathological conditions. Clinical and Experimental Pharmacology Physiology, 39 (2), 168-178.

26. Chernova, V.M. (2017). Mnogofaktornost patogenezane alkogolnoy zhirovoy bolezni pecheni [Multifactorial pathogenesis of alcoholic fatty liver disease]. 
Огляди літератури, оригінальні дослідження, поглядн на Suchasna hastroenterolohiia - Modern Gastroenterology, 6 (98), 92-101 [in Russian].

27. Chesnokova, L.V., Petrov, I.M., Troshina, I.A., \& Medvedeva, I.V. (2013). Soderzhaniye provospalitelnykh tsitokinov v zavisimosti ot stadii fibroza u bolnykh s metabolicheskim sindromom i nealkogolnoy zhirovoy boleznyu pecheni [Content of proinflammatory cytokines depending on the stage of fibrosis in patients with metabolic syndrome and non-alcoholic fatty liver disease]. Klinicheskaya medetsina - Clinicl Medicone, 12 (91), 34-38. [in Russian].

28. Wieckowska, A., Papouchado, B.G., \& Li, Z. (2008). Increased hepatic and circulating interleukin-6 levels in human non-alcoholic steatohepatitis. Am. J. Gastroenterol., 103, 1372-1379.

29. Buyeverov, A.O., \& Bogomolov, P.O. (2012). «Tsitokinovyy vzryv» i progressirovaniye nealkogolnogo steatogepatita ["Cytokine burst" and the progression of non-alcoholic steatohepatitis]. Klin. perspektivy gastroenterol. Gepatol. - Clinical Prospects of Gastroenterology and Gepatology, 5, 12-18 [in Russian].

30. Abiru, S., Migita, K., \& Maeda, Y., (2006). Serum cytokine and soluble cytokine receptor levels in patients with non-alcoholic steatohepatitis. Liver Internatial, 26, 39-45.

31. Petta, S., Grimaudo, S., \& Camma, C. (2012). IL28B and PNPLA3 polymorphisms affect histological liver damage in patients with non-alcoholic fatty liver disease. Journal of Hepatology, 56 (6), 1356-1362.

32. Hernaez, R., Lazo, M., \& Bonekamp, S. (2011). Diagnostic accuracy and reliability of ultrasonography for the detection of fatty liver: ameta-analysis. Hepatology, 54 (3), 1082-1090.

33. Suh, Y.G., \& Jeong, W.I. (2011). Hepatic stellate cells and innate immunity in alcoholic liver disease. World Journal of Gastroenterology, 17 (20), 2543-2551.

34. Mammayev, S.N., Bagomedova, N.V., \& Bogomolov, P.O. (2007). Tsitokinovaya sistema pri nealkogolnom steatogepatite [The cytokine system in non-alcoholic steatohepatitis]. Ros. zhurn. gastroenterol. gepatol. Koloproktol. - Russian Journal of Gastroenterology, Gepatology, Coloproctology, 4, 35-39 [in Russian].

35. Leeming, D., He, Y., \& Veidal, S. (2011). A novel marker fo rassessment of liver matrix remodeling: anenzyme-linked immune sorbent assay (ELISA) detecting a MMP generated type I collagen neo-epitope (C1M). Biomarkers, 16 (7), 61-628.

36. Hospodarskyy, I.Ya., Gavryliuk, N.M., \& Prokopchuk, O.V. (2018). Ua Patent No u 2017 10483. Kyiv: The State Enterprise "Ukrainian Industrial Property Institute".

37. Colak, Y., Senates, E., \& Yesil, A. (2013). Assessment of endothelial function in patients with non-alcoholic fatty liver disease. Endocrine, 43, 100-107.

38. Bobrov, A.N. (2011). Tsirroz pecheni: etiologicheskiye, epidemiologicheskiye, kliniko-diagnosticheskiye i profilakticheskiye aspekty po dannym 15-letnego (19962010 gg.) nablyudeniya v mnogoprofilnom gospitale [Cirrhosis of the liver: etiological, epidemiological, clinical, diagnostic and preventive aspects according to the data of 15-year (1996-2010) observation in a multidisciplinary hospital]. Candidate's Extended abstract. Moscow [in Russian].

39. Charlton, M.R., Burns, J.M., \& Pedersen, R.A. (2011). Frequency and outcomes of liver transplantation орлему випадок з практики, короткі повідомлення for nonalcoholic steatohepatitis in the United States. Gastroenterology, 141, 1249-1253

40. Spahis, S., Delvin, E., Borys, J.M., \& Levy, E. (2017). Oxidative stress as a critical factor in nonalcoholic fatty liver disease pathogenesis. Antioxid Redox Signal, 26 (10), 519-541.

41. Komshilova, K.A., Troshina, E.A., \& Ershova, E.V. (2014). Adiponektin i pokazateli metabolizma glyukozy i lipidov na raznykh kliniko-morfologicheskikh stadiyakh nealkogolnoy zhirovoy bolezni pecheni u bolnykh abdominalnym ozhireniyem [Adiponectin and indicators of glucose and lipid metabolism at different clinical and morphological stages of non-alcoholic fatty liver disease in patients with abdominal obesity]. Terapevt. Arkhiv - Therapeutic Archieve, 10, 27-32 [in Russian].

42. Balukova, E.V., \& Uspenskiy, Yu.P. (2014). Nealkogolnaya zhirovaya bolezn pecheni i metabolicheskiy sindrom [Non-alcoholic fatty liver disease and metabolic syndrome]. Gastroenterologiya - Gastroenterology, 1, 45-48 [in Russian].

43. Vyalov, S.S. (2014). Zhirovaya bolezn pecheni: osobennosti patogeneza, diagnostika i terapevticheskiy potentsial [Fatty liver disease: features of pathogenesis, diagnosis and therapeutic potential]. Consilium Medicum. Gastroenterologiya - Consilium Medicum. Gastroenterology, 8, 72-77 [in Russian].

44. Manne, V., Handa, P., \& Kowdley, K.V. (2018). Pathophysiology of nonalcoholic fatty liver disease / nonalcoholic steatohepatitis. Clinical Liver Disease, 22 (1), 23-37.

45. Melnichenko, G.A., Eliseyeva, A.Yu., \& Mayevskaya, M.V. (2012). Rasprostranennost nealkogolnoy zhirovoy bolezni pecheni pri ozhirenii i eye vzaimosvyaz s faktorami riska serdechno-sosudistykh zabolevaniy i sakharnogo diabeta 2-go tipa [Prevalence of non-alcoholic fatty liver disease in obesity and its relationship with risk factors for cardiovascular diseases and type 2 diabetes mellitus]. Rossiyskiy zhurnal gastroenterologii, gepatologii, koloproktologii - Russian Journal of Gastroenterology, Gepatology, Coloproctology, 5, 45-52 [in Russian].

46. Kwon, Y.M., Oh, S.W., \& Hwang, S.S. (2012). Association of non-alcoholic fatty liver disease with components of metabolic syndrome according to body mass index in Korean adults. Am. J. Gastroenterology, 107, 1852-1858.

47. Fadyeyenko, G.D., \& Nikiforova, Ya.V. (2016). Osoblyvosti kharchovoi povedinky khvorykh na nealkoholnyi steatohepatyt z nadlyshkovoiu masoiu tila abo ozhyrinniam na tli arterialnoi hipertenzii [Features of eating behavior of patients with non-alcoholic steatohepatitis with overweight or obesity on the background of hypertension]. Suchasna hastroenterolohiia - Modern Gastroenterology, 2, 7-14 [in Ukrainian].

48 Mittendorfer, B., Yoshino, M., Patterson, B.W., \& Klein, S. (2016). VLDL triglyceride kinetics in lean, overweight, and obese men and women. Journal of Clinical Endocrinology \& Metabolism, 101, 4151-4160.

49. Dalleck, L.C., Van Guilder, G.P., \& Richardson, T.B. (2014). A community-based exercise intervention transitions metabolically abnormal obese adults to a metabolically healthy obese phenotype. Diabetes, Metabolic Syndrome and Obesity, 7, 369-380.

50. Angulo, P., Hui, J.M., \& Marchesini, G. (2007). NAFLD fibrosis score A noninvasive system that identifies 
Огляди літератури, оригінальні дослідження, погляд на проблему, випадок з практики, короткі повідомлення liver fibrosis in patients with NAFLD. Hepatology, 45 (4), 846-854.

51. Machado, M.V., \& Cortez-Pinto, H. (2013). Noninvasive diagnosis of non-alcoholic fatty liver disease. A critical appraisal. Journal of Hepatology, 58, 1007-1019.

52. Toouli, J., Fried, M., \& Khan, A.G. (2009). Obesity World Gastroenterology Organisation Global Guideline. WGO Global Guideline. Obesity, 30.

\title{
ОЦЕНКА ВЛИЯНИЯ НАЛИЧИЯ У ПАЦИЕНТОВ ИЗБЫТОЧНОЙ МАССЫ ТЕЛА НА ФИБРОЗ ПЕЧЕНИ
}

\author{
○Н. М. Гаврилюк, И. Я. Господарский, А. В. Прокопчук, М. Е. Гаврилюк
}

Тернопольский национальный медицинский университет имени И. Я. Горбачевского МОз Украины

РЕЗЮМЕ. Хронические диффузные воспалительные заболевания печени, избыточная масса тела и ожирение в последние десятилетия остаются серьезной причиной заболеваемости, смертности и инвалидизации населения.

Цель - сравнить влияние избыточной массы тела на течение фиброза у пациентов со стеатозом печени и у пациентов-реконвалесцентов HCV-инфекции.

Материал и методы. В исследование было включено 115 больных с фиброзом печени. В первую группу вошли больные, вылечившиеся от HCV-инфекции ( $n=56)$, вторую группу составили пациенты с НАЖБП ( $n=59)$. О6следуемые каждой группы были поделены на подгруппы в зависимости от массы тела в соответствии с классификацией ИМТ, принятой ВОЗ (1997).

Результаты. Наличие избыточной массы тела существенно влияет на клиническое течение патологического процесса фиброзирования печени, что проявилось развитием цитолитического синдрома. Отмечался рост показателей печеночных проб в биохимическом анализе крови при увеличении массы тела. Обнаружена прямая умеренная взаимосвязь между ИМТ и АЛТ, АСТ. Показатели трансаминаз также коррелировали с фиброзом печени и данными эластографии. Одновременно в этой категории больных диагностировали прогностически неблагоприятные показатели нарушений липидного обмена, а сам фиброз имел тенденцию к прогрессированию.

Выводы. 1. Установлено достоверную корреляцию ИМТ с уровнями АЛТ и АСТ в крови ( $r=0,679, p<0,05$ и r=0,674, p<0,05), что при дальнейшем увеличении избыточной массы тела может привести к переходу стеатоза в стеатогепатит.

2. По данным липидограммы установлена зависимость нарушений липидного спектра от ИМт. Лица с избыточным весом и ожирением 1 степени больше подвержены гиперхолестеринемии, гипертриглицеридемии $(r=0,318, p<0,05)$ на фоне уменьшения XС лПВП $(r=-0,219, p<0,05)$. Данные нарушения являются неблагоприятным фактором течения стеатоза, а при сочетании с фиброзом способствуют его прогрессированию.

3. Избыточная масса тела и ожирение являются основой для развития фиброзных процессов в печени $(r=0,74, p<0,05)$, а ее значительное увеличение приводит к выраженным фибротическим изменениям (F2 - F3 по METAVIR).

КЛЮЧЕВЫЕ СЛОВА: фиброз; избыточная масса тела; ожирение.

\section{ASSESSMENT OF THE OVERWEIGHT INFLUENCE ON LIVER FIBROSIS @N. M. Gavryliuk, I. Ya. Hospodarskyy, O. V. Prokopchuk, M. E. Havrylyuk I. Horbachevsky Ternopil National Medical University}

SUMMARY. Chronic diffuse inflammatory liver disease, overweight and obesity in recent decades continue to be a serious cause of morbidity, mortality and disability.

The aim - to compare the effect of excess body weight on the fibrosis course in patients with hepatic steatosis and patients with convalescence of HCV infection.

Material and Methods. The study included 115 patients with liver fibrosis. Participants were divided into two groups. Group 1 included patients treated for HCV infection $(n=56)$, group 2 consisted of patients with NAFLD ( $n=59$ ). Patients from each group were divided into subgroups depending on their body weight according to the classification of BMI (adopted by the WHO (1997).

Results. The presence of excess body weight significantly affects the clinical course of the pathological liver fibrosis process which manifested itself in the development of cytolytic syndrome. There was a growth rates of liver function tests in the biochemical blood analysis with increasing body weight. A direct moderate relationship between BMI and ALT, AST was detected. Transaminases were also correlated with liver fibrosis and elastography data. Simultaneously, this category of patients is diagnosed with prognostically unfavorable indicators of lipid metabolism disorders, and fibrosis itself tends to progress. 
Огляди літератури, оригінальні дослідження, погляд на проблему, випадок з практики, короткі повідомлення

Conclusions: 1. The correlation of BMI with the level of ALT and AST in the blood was established $(r=0.679, p<0.05$ and $r=0.674, p<0.05$ ), which with a further increase in excess body weight can lead to the transition from steatosis to steatohepatitis.

2. According to the lipid profile, the dependence of lipid spectrum disorders on BMI was established. People with overweight and obesity grade I are more predisposed to hypercholesterolemia, hypertriglyceridemia $(r=0.318, p<0.05)$ on the background of reduced HDL cholesterol $(r=-0.219, p<0.05)$. These disorders are an unfavorable factor in the course of steatosis, and in combination with fibrosis contributes to its progression.

3. Overweight and obesity are the basis for the development of fibrotic processes in the liver $(r=0.74, p<0.05)$, and its significant increase leads to pronounced fibrotic changes (F2 -F3 by METAVIR).

KEY WORDS: fibrosis; overweight and obesity. 